\title{
Syntheses and Structures of 2-Acetylpyridine-(2-amino-benzoylhydrazone) and its Dioxouranium(VI) Complex
}

\author{
Claudia C. Gatto, ${ }^{a}$ Ernesto S. Lang, ${ }^{*, a}$ Robert A. Burrow ${ }^{a}$ and Ulrich Abram ${ }^{b}$ \\ ${ }^{a}$ Universidade Federal de Santa Maria, Departamento de Química, 97105-900 Santa Maria-RS, Brazil \\ ${ }^{b}$ Freie Universität Berlin, Institute of Chemistry, Fabeckstr. 34-36, D-14195 Berlin, Germany
}

\begin{abstract}
A síntese e a caracterização da 2-acetilpiridina-(2-aminobenzoilhidrazona) (HL ${ }^{1}$ ) e do seu primeiro complexo com dióxido de urânio são descritas neste trabalho. A análise estrutural da hidrazona, $\mathrm{HL}^{1}$, por difração de raios $\mathrm{X}$ do monocristal, mostra que sua estrutura molecular é quase planar no estado sólido, apresentando ligações de hidrogênio intermoleculares. O complexo $\left[\mathrm{UO}_{2}\left(\mathrm{~L}^{1}\right)(\mathrm{dmf})_{2}\right]\left(\mathrm{NO}_{3}\right)$ é formado a partir de uma suspensão em refluxo de $\mathrm{HL}^{1}$ com nitrato de uranila em metanol, na presença de pequena quantidade de trietilamina. A recristalização em dmf resulta na obtenção de cristais adequados para a difração de raios X. A análise por difração de raios $\mathrm{X}$ do complexo mostra uma geometria de coordenação bipiramidal de base pentagonal para o urânio(VI), formada pelos oxigênios da uranila nas posições apicais, uma molécula da hidrazona monodesprotonada e dois átomos de oxigênio das moléculas de dimetilformamida nas posições equatoriais.
\end{abstract}

We describe the synthesis and characterization of 2-acetylpyridine-(2-aminobenzoylhydrazone) $\left(\mathrm{HL}^{1}\right)$ and its first dioxouranium complex. The single crystal X-ray structural analysis of the hydrazone, $\mathrm{HL}^{1}$, reveals an almost planar structure with intermolecular hydrogen bonds. The complex $\left[\mathrm{UO}_{2}\left(\mathrm{~L}^{1}\right)(\mathrm{dmf})_{2}\right]\left(\mathrm{NO}_{3}\right)$ is formed by refluxing a suspension of $\mathrm{HL}^{1}$ with uranyl nitrate in methanol in the presence of a small quantity of triethylamine. Recrystallisation from dmf results in single crystals suitable for X-ray crystallography. The single crystal X-ray study of the complex shows a distorted pentagonal-bipyramidal coordination geometry around the uranium(VI) center, determined by two axial oxo ligands, two nitrogen and one oxygen atoms from a chelating monodeprotonated hydrazone and the oxygen donor atoms of two dimethylformamide molecules.

Keywords: uranium; hydrazones, actinides, structure analysis

\section{Introduction}

Schiff base complexes of uranium have aroused interest on account of their stability, high coordination numbers and usefulness in selective chemical separations. Uranyl complexes of ligands with $\mathrm{O}$ and $\mathrm{N}$ donors have been extensively reviewed and quite a few complexes of hydrazone Schiff bases have been reported. ${ }^{1,2}$ As part of our systematic studies on the coordination chemistry of the early actinide elements, we recently published a report on the structural chemistry of thiosemicarbazonato complexes of uranium(VI). ${ }^{3}$

The formation of complexes with moderate stability is observed with acetylpyridine thiosemicarbazone. The

*e-mail: eslang@quimica.ufsm.br presence of the pyridine nitrogen atom is essential for the formation of chelate complexes. This additional donor site is obviously essential to establish a bond between the relatively 'hard' $\mathrm{UO}_{2}{ }^{2+}$ ions and 'soft' donor sites such as the thione sulphur atoms in thiosemicarbazones. More stable complexes are expected with 'harder' donor atoms such as oxygen, as provided by semicarbazones or hydrazones. A number of studies have been undertaken with both ligand systems and the formation of chelates with various compositions has been suggested on the basis of spectroscopic data. ${ }^{4}$ Some derivatives of semicarbazones or hydrazones can be used for the spectrophotometric determination of metal ions including $\mathrm{UO}_{2}^{2+.5}$. In view of the structural interest involved in the coordination chemistry of uranium with Schiff base ligands, the synthesis and characterization of the Lewis base 2-acetylpyridine-(2- 
aminobenzoylhydrazone) and the first dioxouranium complex with this hydrazone are reported in this paper.

\section{Experimental}

Caution! Uranium is a toxic metal and both ${ }^{235} U$ and ${ }^{238} U$ are radioactive isotopes. Good laboratory practices should be employed when working with any uranic material.

$\mathrm{UO}_{2}\left(\mathrm{NO}_{3}\right)_{2} \cdot 6 \mathrm{H}_{2} \mathrm{O}$ was purchased from Merck. $\left(\mathrm{NBu}_{4}\right)_{2}\left[\mathrm{UO}_{2} \mathrm{Cl}_{4}\right]$ was prepared following a standard procedure from uranyl nitrate, aqueous $\mathrm{HCl}$ and tetrabutylammonium chloride. Infrared spectra were recorded for $\mathrm{KBr}$ pellets on a Shimadzu FTIR spectrophotometer between 4000 and $400 \mathrm{~cm}^{-1}$. A Jeol FX400 NMR spectrometer was used to record the ${ }^{1} \mathrm{H}$ NMR spectra.

\section{$H L^{1}$}

2-Acetylpiridine ( $0.34 \mathrm{~mL}, 3 \mathrm{mmol})$ was added to a solution of 2-aminobenzoylhydrazide ( $453 \mathrm{mg}, 3 \mathrm{mmol}$ ) dissolved in $20 \mathrm{~mL}$ of aqueous ethanol $(1: 1 \mathrm{v} / \mathrm{v})$. The mixture was heated at reflux for $4 \mathrm{~h}$ and a yellow solution was formed. Single crystals suitable for X-ray diffraction analysis were obtained directly from the mother liquor upon standing overnight at room temperature. Yield: $708 \mathrm{mg}, 93 \%$. Elemental Analysis (Found/Calc. for $\mathrm{C}_{14} \mathrm{H}_{14} \mathrm{~N}_{4} \mathrm{O}$ ): C, 66.05/ 66.13; H, 5.68/5.55; N, 22.37/22.03\%. IR v $v_{\max } / \mathrm{cm}^{-1}: 1705.0$ $(\mathrm{C}=\mathrm{O}), 1593.1,1473.5(\mathrm{C}=\mathrm{N}) .{ }^{1} \mathrm{H}$ NMR $(400 \mathrm{MHz}$, DMSO$\left.d_{6}\right), \delta(\mathrm{ppm}): \mathrm{CH}_{3} 2.45(\mathrm{~s}, 3 \mathrm{H})$; phenyl 6.27-8.64 (m, 8H); NH 10.67 (s, 1H).
$\left[U O_{2}\left(L^{l}\right)(d m f)_{2}\right]\left(N_{3}\right)$

$\mathrm{HL}^{1}(50 \mathrm{mg}, 2 \mathrm{mmol}$ ) was partially dissolved in $10 \mathrm{~mL}$ of methanol and added to a solution of $\mathrm{UO}_{2}\left(\mathrm{NO}_{3}\right)_{2} \cdot 6 \mathrm{H}_{2} \mathrm{O}(100$ $\mathrm{mg}, 2 \mathrm{mmol}$ ) in $5 \mathrm{~mL}$ of methanol. A few drops of $\mathrm{NEt}_{3}$ were added and the mixture was heated at reflux for $2 \mathrm{~h}$. An orange powder was formed and filtered off. Single crystals suitable for X-ray diffraction analysis were obtained by slow cooling of a hot dmf solution. Yield: $94.7 \mathrm{mg}, 65 \%$. Elemental Analysis, (Found/Calc. for $\left.\mathrm{C}_{20} \mathrm{H}_{27} \mathrm{~N}_{7} \mathrm{O}_{8} \mathrm{U}\right): \mathrm{C}, 32.62 / 32.84 ; \mathrm{H}, 3.48 / 3.72 ; \mathrm{N}, 13.83 /$ $13.40 \%$. IR $v_{\text {max }} / \mathrm{cm}^{-1}: 1654.8(\mathrm{C}=\mathrm{O}), 1539.1(\mathrm{C}=\mathrm{N}), 894.9$ $(\mathrm{O}=\mathrm{U}=\mathrm{O})$. The same procedure can be used when the reaction is performed with $\left(\mathrm{NBu}_{4}\right)_{2}\left[\mathrm{UO}_{2} \mathrm{Cl}_{4}\right]$ instead of uranyl nitrate.

\section{$X$-ray structure determinations}

The X-ray diffraction data were collected on a Bruker Kappa APEX II single crystal diffractometer with Mo $\mathrm{K}_{\alpha}$ radiation $(0.71073 \AA)$. SADABS was used to scale the data and perform the multi-scan absorption correction. The structures were solved by direct methods using SHELXS-97. ${ }^{6}$ Subsequent Fourier-difference map analyses yielded the positions of the non-hydrogen atoms. Refinement was performed using SHELXL-97. ${ }^{7}$ Hydrogen atoms were placed in idealized positions and treated with the 'riding model' option of SHELXL97. Crystal data and more details of data collections and refinements are presented in Table 1. Selected bond lengths and bond angles are given in Table 2.

Table 1. X-ray structure data collection and refinement parameters

\begin{tabular}{lll}
\hline & $\mathrm{HL}^{1}$ & {$\left[\mathrm{UO}_{2}\left(\mathrm{~L}^{1}\right)\left(\mathrm{dmf}_{2}\right]\left(\mathrm{NO}_{3}\right)\right.$} \\
\hline Formula & $\mathrm{C}_{14} \mathrm{H}_{14} \mathrm{~N}_{4} \mathrm{O}$ & $\mathrm{C}_{20} \mathrm{H}_{27} \mathrm{~N}_{7} \mathrm{O}_{8} \mathrm{U}$ \\
$\left.\mathrm{M} /(\mathrm{g} \mathrm{mol})^{-1}\right)$ & 2554.29 & 731.52 \\
Crystal system & Orthorhombic & $C 2 / c$ \\
Space group & $P b c a$ & \\
Unit cell & & $26.237(1)$ \\
$a /(\AA)$ & $11.475(2)$ & $7.945(4)$ \\
$b /(\AA)$ & $14.766(3)$ & $25.455(1)$ \\
$c /(\AA)$ & $15.177(3)$ & $107.507(3)$ \\
$\beta /\left({ }^{\circ}\right)$ & 90 & $5061.0(4)$ \\
$V /\left(\AA^{3}\right)$ & $2571.6(8)$ & 8 \\
$\mathrm{Z}$ & 8 & 6.472 \\
Linear absorption coefficient/(mm & \\
Measured reflections & 0.087 & 31092 \\
Independent reflections $\left./ R_{\text {int }}\right)$ & 12645 & $7429 / 0.0411$ \\
Refined parameters & $3562 / 0.0492$ & 325 \\
$\mathrm{t}_{\min } / \mathrm{t}_{\text {max }}$ & 169 & $0.5955 / 1.00$ \\
$\mathrm{~F}(000)$ & $0.7904 / 1.00$ & 2816 \\
Goodness-of-fit $\left(F^{2}\right)$ & 1072 & 0.854 \\
$R_{1}(\mathrm{~F}) / w R_{2}\left(F^{2}\right)(I>2 \sigma(I))^{\mathrm{a}}$ & 0.994 & $0.0295 / 0.0776$ \\
\hline
\end{tabular}

${ }^{\mathrm{a}} R_{1}=\left|F_{o}-F_{c}\right| /\left|F_{o}\right| ; w R_{2}=\left[w\left(F_{o}^{2}-F_{c}^{2}\right)^{2} /\left(w F_{o}^{2}\right)\right]^{-1 / 2}$. 
Table 2. Selected bond lengths $(\AA)$ and bond angles $\left({ }^{\circ}\right)$ for $\mathrm{HL}^{1}$ and $\left[\mathrm{UO}_{2}\left(\mathrm{~L}^{1}\right)(\mathrm{dmf})_{2}\right]\left(\mathrm{NO}_{3}\right)$

\begin{tabular}{ll}
\hline $\mathrm{HL}^{1}$ & {$\left[\mathrm{UO}_{2}\left(\mathrm{~L}^{1}\right)(\mathrm{dmf})_{2}\right]\left(\mathrm{NO}_{3}\right)$} \\
\hline $\mathrm{C}(6)-\mathrm{N}(2)=1.295(2)$ & $\mathrm{U}(1)-\mathrm{O}(20)=1.761(4)$ \\
$\mathrm{N}(2)-\mathrm{N}(3)=1.366(2)$ & $\mathrm{U}(1)-\mathrm{O}(1)=2.298(4)$ \\
$\mathrm{N}(3)-\mathrm{C}(8)=1.360(2)$ & $\mathrm{U}(1)-\mathrm{N}(1)=2.581(4)$ \\
$\mathrm{N}(4)-\mathrm{C}(12)=1.354(2)$ & $\mathrm{U}(1)-\mathrm{N}(2)=2.513(4)$ \\
$\mathrm{N}(1)-\mathrm{C}(1)=1.330(2)$ & $\mathrm{C}(6)-\mathrm{N}(2)=1.297(6)$ \\
$\mathrm{O}(1)-\mathrm{C}(8)=1.228(2)$ & $\mathrm{U}(1)-\mathrm{O}(2)=2.365(4)$ \\
$\mathrm{N}(3)-\mathrm{H}(3) \cdot \mathrm{N}(1)=2.617(2)$ & $\mathrm{U}(1)-\mathrm{O}(3)=2.329(4)$ \\
$\mathrm{N}(4)-\mathrm{H}(4 \mathrm{~B}) \cdots \cdot \mathrm{O}(1)=2.667(2)$ & $\mathrm{N}(4)-\mathrm{H}(4 \mathrm{~B}) \cdots \mathrm{N}(3)=2.705(7)$ \\
$\mathrm{N}(4)-\mathrm{H}(4 \mathrm{~A}) \cdot \mathrm{N}(2)^{\mathrm{i}}=3.126(2)$ & $\mathrm{N}(4)-\mathrm{H}(4 \mathrm{~A}) \cdots \mathrm{O}(5)^{\mathrm{ii}}=3.145(8)$ \\
$\mathrm{O}(1)-\mathrm{C}(8)-\mathrm{N}(3)=120.95(1)$ & $\mathrm{O}(10)-\mathrm{U}(1)-\mathrm{O}(20)=176.23(2)$ \\
$\mathrm{C}(6)-\mathrm{N}(2)-\mathrm{N}(3)=118.57(1)$ & $\mathrm{O}(1)-\mathrm{U}(1)-\mathrm{N}(2)=62.84(1)$ \\
$\mathrm{O}(1)-\mathrm{C}(8)-\mathrm{C}(11)=123.93(1)$ & $\mathrm{N}(2)-\mathrm{U}(1)-\mathrm{N}(1)=62.83(1)$ \\
$\mathrm{N}(3)-\mathrm{C}(8)-\mathrm{C}(11)=115.12(1)$ & $\mathrm{O}(1)-\mathrm{U}(1)-\mathrm{O}(2)=157.01(1)$ \\
$\mathrm{C}(8)-\mathrm{N}(2)-\mathrm{N}(3)=118.57(1)$ & $\mathrm{O}(1)-\mathrm{U}(1)-\mathrm{O}(3)=78.63(1)$ \\
& $\mathrm{O}(20)-\mathrm{U}(1)-\mathrm{N}(2)=90.63(2)$ \\
& $\mathrm{O}(10)-\mathrm{U}(1)-\mathrm{O}(3)=90.63(2)$ \\
\hline
\end{tabular}

Symmetry operations: ${ }^{\mathrm{i}} \mathrm{x}-1 / 2,-\mathrm{y}+1 / 2-\mathrm{z}+1 ;{ }^{\mathrm{ii}}-\mathrm{x}+1, \mathrm{y}+1,-\mathrm{z}+1 / 2$

\section{Results and Discussion}

The synthesis of 2-acetylpyridine-(2-aminobenzoylhydrazone), $\mathrm{HL}^{1}$, was performed by a condensation reaction in almost quantitative yield. The single crystal X-ray analysis of the product shows that the molecule is almost planar, with the pyridine ring $\mathrm{N}(1)-\mathrm{C}(5)$ (r.m.s. $=0.0071 \AA$ ) and the phenyl ring $\mathrm{C}(11)-\mathrm{C}(16)$ (r.m.s. $=0.0062 \AA$ ) lying $2.70(1)^{\circ}$ and $12.93(9)^{\circ}$ away, respectively, from the mean plane of the $\mathrm{HN}_{2} \mathrm{CO}$ central unit. The double bonds $\mathrm{N}(2)=\mathrm{C}(6)$ and $\mathrm{C}(8)=\mathrm{O}(1)$ are localized, with bond lengths of $1.295(2)$ and 1.228(2) $\AA$, respectively. The distance $\mathrm{N}(2)-\mathrm{N}(3)$ of $1.366(2) \AA$ is intermediate between those of an N-N single bond $(1.425(27) \AA)^{8}$ and an $\mathrm{N}=\mathrm{N}$ double bond $(1.222(6) \AA) .{ }^{8}$ Figure 1 shows an representation of the molecular structure of $\mathrm{HL}^{1}$.

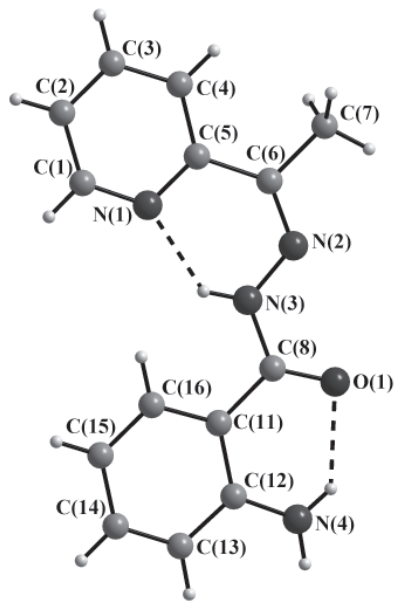

Figure 1. Graphical representation of the molecular structure of the 2-acetylpyridine-(2-aminobenzoylhydrazone). ${ }^{10}$
Selected bond lengths and bond angles are given in Table 2.

The results of spectroscopic and X-ray diffraction studies of $\mathrm{HL}^{1}$ indicate the protonation of the $\mathrm{N}(3)$ atom and the formation of intramolecular hydrogen bonds $\mathrm{N}(3)-$ $\mathrm{H}(3) \cdots \mathrm{N}(1)$ and $\mathrm{N}(4)-\mathrm{H}(4 \mathrm{~B}) \cdots \mathrm{O}(1)$ (Table 3). Additionally, the intermolecular hydrogen bond $\mathrm{N}(4)-\mathrm{H}(4 \mathrm{~A}) \cdots \mathrm{N}(2)^{\mathrm{i}}$ is observed in the crystal structure (symmetry operation: $\left.{ }^{\mathrm{i}} \mathrm{x}+1 / 2,-\mathrm{y}+1 / 2-\mathrm{z}+1\right)$. The molecules are packed in layers parallel to the $a c$ plane and are held together essentially by van der Waals interactions.

$\mathrm{UO}_{2}\left(\mathrm{NO}_{3}\right)_{2} \cdot 6 \mathrm{H}_{2} \mathrm{O}$ or $\left(\mathrm{NBu}_{4}\right)_{2}\left[\mathrm{UO}_{2} \mathrm{Cl}_{4}\right]$ react with 2-acetylpyridine-(2-aminobenzoyl-hydrazone) to form an orange precipitate. The composition of the product is solvent dependent due to solvent complexation at the free coordination sites trans to the hydrazone. The crystal structure determination confirms that two molecules of dimethylformamide bind to the uranium center, producing $\left[\mathrm{UO}_{2}\left(\mathrm{~L}^{1}\right)(\mathrm{dmf})_{2}\right]\left(\mathrm{NO}_{3}\right)$ when the reaction is performed in $\mathrm{dmf}$ and the product is crystallized from that solvent. The hydrazone binds in its mono-deprotonated form. An representation of the molecular structure is illustrated in Figure 2 and selected bond lengths and angles are given in Table 2. The coordination sphere of the metal center can be described as a distorted pentagonal bipyramid with the oxo ligands in the axial positions and with a planar equatorial coordination environment (maximum deviation from the mean least-square plane formed by the atoms $\mathrm{U}(1), \mathrm{N}(1), \mathrm{N}(2), \mathrm{O}(1), \mathrm{O}(2)$ and $\mathrm{O}(3)$ : r.m.s. $0.0466 \AA$ ). The X-ray structural analysis confirms the spectroscopic conclusion that the $\mathrm{NH}_{2}$ group of the hydrazone is not involved in coordination to the metal center. The infrared spectrum of the complex shows a band at $2800 \mathrm{~cm}^{-1}$, which suggests hydrogen bonds in the solid state and could be assigned to the $\mathrm{NH}_{2}$ group. The presence of the $\mathrm{UO}_{2}^{2+}$ unit is confirmed by a strong band at $894.9 \mathrm{~cm}^{-1}$, and the

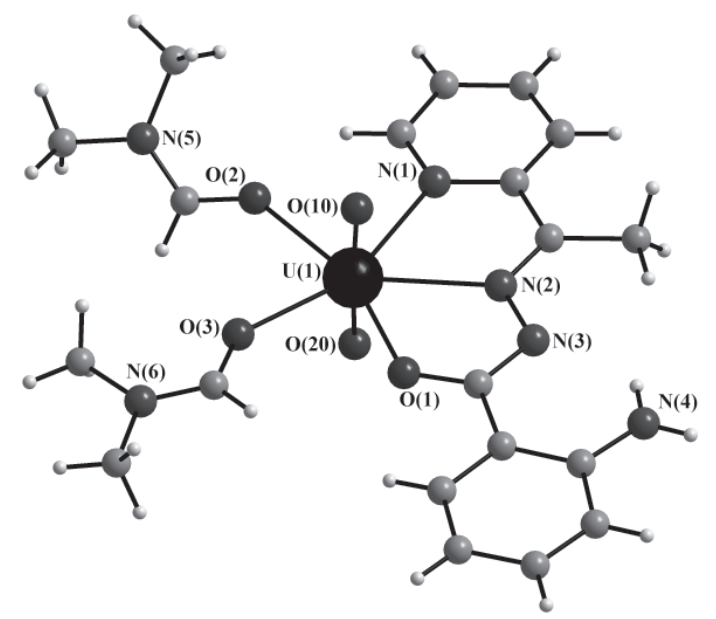

Figure 2. Graphical representation of the molecular structure of $\left[\mathrm{UO}_{2}\left(\mathrm{~L}^{1}\right)(\mathrm{dmf})_{2}\right]^{+} .^{10}$ 
Table 3. Hydrogen bonding distances $(\AA)$ and angles $\left(^{\circ}\right)$ in $\mathrm{HL}^{1}$ and $\left[\mathrm{UO}_{2}\left(\mathrm{~L}^{1}\right)(\mathrm{dmf})_{2}\right]\left(\mathrm{NO}_{3}\right)$

\begin{tabular}{lcccc}
\hline $\mathrm{D}-\mathrm{A} \cdots \mathrm{H}$ & $\mathrm{d}(\mathrm{D}-\mathrm{H})$ & $\mathrm{d}(\mathrm{H} \cdots \mathrm{A})$ & $\mathrm{d}(\mathrm{D} \cdots \mathrm{A})$ & $<(\mathrm{DHA})$ \\
\hline $\mathrm{HL}^{1}$ & & & & \\
$\mathrm{~N}(3)-\mathrm{H}(3) \cdots \mathrm{N}(1)$ & 0.86 & 1.94 & $2.617(2)$ & $134.6(9)$ \\
$\mathrm{N}(4)-\mathrm{H}(4 \mathrm{~B}) \cdots \mathrm{O}(1)$ & 0.86 & 2.02 & $2.677(2)$ & $131.3(5)$ \\
$\mathrm{N}(4)-\mathrm{H}(4 \mathrm{~A}) \cdots \mathrm{N}(2)^{\mathrm{i}}$ & 0.86 & 2.34 & $3.126(2)$ & \\
{$\left[\mathrm{UO} \mathrm{L}_{2}\left(\mathrm{~L}^{1}\right)(\mathrm{dmf})_{2}\right]\left(\mathrm{NO}_{3}\right)$} & & & & 130.4 \\
$\mathrm{~N}(4)-\mathrm{H}(4 \mathrm{~B}) \cdots \mathrm{N}(3)$ & 0.86 & 2.07 & $2.705(7)$ & 132.0 \\
$\mathrm{~N} 4-\mathrm{H}(4 \mathrm{~A}) \cdots \mathrm{O}(5)^{\mathrm{ii}}$ & 0.86 & 2.50 & $3.145(8)$ & \\
\hline
\end{tabular}

Symmetry operations: ${ }^{\mathrm{i}} \mathrm{x}-1 / 2,-\mathrm{y}+1 / 2-\mathrm{z}+1 ;{ }^{\mathrm{ii}}-\mathrm{x}+1, \mathrm{y}+1,-\mathrm{z}+1 / 2$

typical pattern for 2-acetylpyridine-(2-aminobenzoylhydrazone), with $\mathrm{C}=\mathrm{O}$ and $\mathrm{C}=\mathrm{N}$ vibrations, appears between 1654.8 and $1539.1 \mathrm{~cm}^{-1}$.

The hydrazone ligand is almost planar, as a consequence of the constraints imposed by the formation of the pentagonal basal plane. This suggests considerable steric strain for the uranium complex under study. Principal distortions are due to the small bite angles of the hydrazone, which result in bond angles between $62.83(1)$ and $78.63(1)^{\circ}$ for neighboring atoms in the equatorial plane. Deprotonation of the $\mathrm{N}(2)$ atom, which occurs during the formation of the metal complex, results in a shift of the double bonds within the backbone of the ligand, increasing the electron density at the corresponding oxygen and nitrogen atoms and their ability to act as donors to metal ions. A shift of the $\pi$-system of $\mathrm{HL}^{1}$ from $C(6)$ to $C(8)$ and a delocalization of the electron density of the $\mathrm{C}(8)-\mathrm{O}(1)$ double bond over the $\mathrm{N}(3)-\mathrm{C}(8)-\mathrm{O}(1)$ amide system is observed.

The hydrazone unit is deprotonated in the uranium complexes studied in this paper. This is in contrast to the behavior in some lanthanide complexes where no or only partial deprotonation of the $\mathrm{NH}$ groups was observed. ${ }^{9}$ There are intramolecular hydrogen bonds between $\mathrm{N}(4)-$ $\mathrm{H}(4 \mathrm{~B}) \cdots \mathrm{N}(3)$ and intermolecular hydrogen bonds between $\mathrm{N}(4)-\mathrm{H}(4 \mathrm{~A}) \cdots \mathrm{O}(5)^{\mathrm{ii}}$, Table 3 (symmetry operation ${ }^{\mathrm{ii}}-\mathrm{x}+1$, $\mathrm{y}+1,-\mathrm{z}+1 / 2)$.

The present study shows that acetylpyridine benzoylhydrazones are well suitable to form stable complexes with dioxouranium(VI) units. The successful synthesis of the 2-acetylpyridine-(2-aminobenzoylhydrazone) and its uranium complex may constitute a starting point to the development of new ligand systems which can perfectly fit the coordination requirements of lanthanide and actinide ions.

\section{Acknowledgments}

The authors gratefully acknowledge financial support from DAAD, CNPq and FAPERGS-PRONEX Proc. No. 0408175 .

\section{Supplementary Information}

Crystallographic data (excluding structure factors) for the structures in this paper have been deposited with the Cambridge Crystallographic Data Centre, CSD numbers CCDC 606778 and CCDC 609303. Copies of the data can be obtained, free of charge, via www.ccdc.cam.ac.uk/ conts/retrieving.html, or from the Cambridge Crystallographic Data Centre, CCDC, 12 Union Road, Cambridge CB2 1EZ, UK; fax: +44 1223 336033; e-mail: deposit@ccdc.cam.ac.uk.

\section{References}

1. RadeckaParyzek, W.; Jankowska, E.; Luks, E.; Polyhedron 1988, 7, 439; Aggarwal, R.C.; Prasad, B.; J. Inorg. Nucl. Chem. 1971, 33, 3984.

2. Bandoli, G.; Clemente, D.A.; Marangoni, G.; Paolucci, G.; J. Chem. Soc., Chem. Commun. 1978, 235; Paolucci, G.; Marangoni, G.; Inorg. Chim. Acta 1977, 24, L5; Kyriakidis, C.E.; Christidis, P.C.; Rentzeparis, P.J.; Tossidis, I.A.; Z. Kristallogr. 1992, 200, 15; Paolucci, G.; Marangoni, G.; Bandoli, G.; Clemente, D.A.; J. Chem. Soc., Dalton Trans. 1980, 1304; Gulbaev, Y.I.; Azizov, T.A.; Khudoyarov, A.B.; Sharipov, K.T.; Uzb. Khim. Sh.(Russ.)(Uzbek Chem. J.) 1997, 28; Gatto, C.C.; Lang, E.S.; Kupfer, A.; Hagenbach, A.; Wille, D.; Abram, U.; Z. Anorg. Allg. Chem. 2004, 630, 735; Gatto, C.C.; Lang, E.S.; Kupfer, A.; Hagenbach, A.; Abram, U.; Z. Anorg. Allg. Chem. 2004, 630, 1286; Gatto, C. C.; Lang, E.S.; Jagst, A.; Abram, U.; Inorg. Chim. Acta 2004, 357, 4405.

3. Abram, U.; Lang, E.S.; Bonfada, E.; Z. Anorg. Allg. Chem. 2002, 626, 1873.

4. Argawala, B.V.; Hingorani, S.; Gowda, G. A.; Inorg. Chim. Acta 1990, 176, 149; Gandi, J.B.; Kulkarni, N.D.; Transition Met. Chem. 2001, 26, 96; Gandi, J.B.; Kulkarni, N.D.; Transition Met. Chem. 2000, 25, 209; Lal, R.A.; Adhikari, S.; Kumar, A.; Indian J. Chem., Section A 1997, 36, 1063.

5. Agarwal, R.K.; Tyagi, N.; Chakraborti, I.; Egyptian J. Anal. Chem. 1998, 7, 127; Lopez de Alba, P.L.; Ramirez, E.O.; J. Radioanalyt. Nucl. Chem. 1986, 104, 255; Ramachandraiah, C.; 
Vijayakumari, D. ; Lakshminarayana, K.; J. Radioanalyt. Nucl. Chem. 1993, 175, 185; Vijayakumari, D. ; Lakshminarayana, K.; J. Radioanalyt. Nucl. Chem. 1993, 175, 1.

6. Sheldrick, G. M.; SHELXS97- A Program for the Solution of Crystal Structures, University of Göttingen: Germany, 1997.

7. Sheldrick, G. M.; SHELXL97 - A Program for the Refinement of Crystal Structures, University of Göttingen: Germany, 1997.
8. Allen, F. H; Kennard, O.; Watson, D. G.; Brammer, L.; Orpen, A. G.; J. Chem. Soc., Perkin Trans. II 1987, S1.

9. Jagst, A.; Sanchez, A.; Lopez, E.M.V.; Abram, U.; Inorg. Chem. 2005, 44, 5738.

10. Brandenburg, H., DIAMOND - A Program for the Representation of Crystal Structures, Bohn: Germany, 2006.

Received: June 12, 2006

Published on the web: December 1, 2006 